\title{
Sistem Kontrol Pemberian Nutrisi pada Budi Daya Tanaman Aeroponik Berbasis Fuzzy Logic
}

\author{
Arif Safrimawan dan Asrizal Deri Futra* \\ Politeknik Negeri Batam, Batam, Indonesia \\ Email: deri@polibatam.ac.id
}

\begin{abstract}
Abstrak-Metode aeroponik merupakan salah satu cara budi daya tanaman tanpa menggunakan tanah. Aeroponik umumnya digunakan untuk budi daya tanaman jenis sayuran seperti kangkung. Pada metode ini, akar tanaman ditempatkan dalam posisi menggantung. Nutrisi diberikan dalam bentuk ke bagian akar tanaman dengan teknik pengkabutan dengan menggunakan sprayer yang terhubung dengan pompa. Biasanya, pemberian nutrisi diberikan dalam rentang waktu tertentu (timer). Namun dalam sistem ini pemberian nutrisi tidak terlalu efektif. Oleh karena itu, dibuat sistem yang dapat mengontrol pemberian nutrisi sesuai kebutuhan tanaman. Pada sistem ini, yang menjadi parameter yaitu kelembapan dan suhu. Nilai kelembapan dan suhu dari sensor DHT22 akan menjadi input untuk Fuzzy logic, kemudian akan diproses oleh mikrokontroler untuk menghasilkan keluaran sesuai dengan input yang diterima. Nilai output dari mikrokontroler berupa waktu penyalaan akan mengaktifkan pompa yang akan menyuplai larutan nutrisi ke bagian akar. Sistem ini juga dilengkapi dengan data logger, sehingga data dari mikrokontroler dapat disimpan. Alat mampu bekerja menyuplai larutan nutrisi untuk tanaman kangkung dengan set point suhu $33^{\circ} \mathrm{C}$ sedangkan error suhu yaitu $3,32 \%$ $\mathbf{5 , 2 8 \%}$.
\end{abstract}

Kata kunci : Aeroponik, kangkung, sensor DHT22, Fuzzy logic, pompa, data logger

\section{PENDAHULUAN}

AEROPONIK merupakan salah satu metode bercocok tanam dengan media udara. Aeroponik berasal dari kata aero yang berarti udara dan ponos yang berarti daya [1]. Metode ini sangat tepat digunakan untuk budi daya tanaman pada suatu tempat dengan luas terbatas. Pada aplikasinya, tanaman yang ditanam dengan metode ini ditempatkan dalam posisi menggantung. Nutrisi diberikan dengan teknik pengkabutan ke bagian akar tanaman [2]. Beberapa keuntungan yang didapatkan dari metode ini antara lain: kemudahan dalam panen, nutrisi dapat dikontrol, efisien dalam penggunaan lahan serta kadar oksigen yang cukup dalam larutan nutrisi sehingga menguntungkan tanaman [3].

Metode aeroponik dapat digunakan untuk menanam tanaman jenis sayuran. Salah satunya adalah kangkung darat (Ipomoea Reptans Poir). Kangkung darat dapat hidup di dataran rendah dan tinggi pada ketinggian 5-2000 mdpl dengan $\mathrm{pH}$ tanah 5,6-6,5. Kelembapan yang baik bagi kangkung darat yaitu diatas $60 \%$ sedangkan suhu yang ideal berada pada $20-32^{\circ} \mathrm{C}$ [4].
Selama masa penanaman, tanaman membutuhkan nutrisi. Nutrisi yang diberikan berupa air yang dicampur dengan unsur hara makro dan mikro. Unsur hara makro adalah unsur hara yang dibutuhkan dalam jumlah banyak, terdiri atas $\mathrm{C}, \mathrm{H}, \mathrm{O}, \mathrm{N}$, $\mathrm{P}, \mathrm{K}, \mathrm{Ca}, \mathrm{Mg}$ dan S. Sedangkan unsur hara mikro adalah unsur hara yang dibutuhkan dalam jumlah sedikit namun tetap berpengaruh terhadap pertumbuhan tanaman. Unsur hara jenis ini adalah $\mathrm{Mn}, \mathrm{Cu}, \mathrm{Fe}, \mathrm{Mo}, \mathrm{Zn}$ dan B [5].

Untuk memudahkan petani aeroponik dalam menyuplai nutrisi tanaman digunakan sistem pengaturan waktu (timer) yang terhubung dengan sprayer. Sprayer tersebut akan menyuplai nutrisi tanaman sesuai dengan waktu yang ditentukan. Namun, pemberian nutrisi dengan sistem ini masih memiliki beberapa kekurangan yaitu, pertumbuhan tanaman yang belum sempurna dikarenakan pemberian nutrisi tidak merata [6].

Maka dari itu, dibutuhkan sebuah sistem pemberian nutrisi tanaman kangkung yang dapat menyuplai nutrisi secara tepat. Sistem tersebut bekerja dengan Fuzzy logic. Pemberian nutrisi bergantung pada kelembapan dan suhu. Dengan adanya sistem ini, diharapkan suplai nutrisi tanaman kangkung dapat terkontrol dengan baik

\section{TEORI}

\section{A. Konsep Aeroponik}

The international union of soil-less culture mendefinisikan aeroponik sebagai suatu sistem bercocok tanam dimana bagian akar tanaman secara berkala diberi tetesan halus nutrisi (berupa kabut atau aerosol) [2]. Penggunaan teknik aeroponik dalam bercocok tanam memiliki beberapa keuntungan, di antaranya: kemudahan dalam panen, nutrisi dapat dikontrol, efisien dalam penggunaan lahan serta kadar oksigen yang cukup dalam larutan nutrisi sehingga menguntungkan tanaman [3].

\section{B. Tanaman Kangkung}

Kangkung darat (Ipomoea Reptans Poir) adalah tanaman semusin atau tahunan yang berasal dari kawasan Asia Tenggara dan Asia Selatan. Sayuran kangkung relatif mudah dibudidayakan, berumur pendek dan memiliki harga yang cukup murah.

Kangkung darat dapat hidup di dataran rendah dan tinggi pada ketinggian 5-2000 mdpl dengan $\mathrm{pH}$ tanah 5,6-6,5. Kelembapan yang baik bagi kangkung darat yaitu di atas $60 \%$, sedangkan suhu yang ideal berada pada $20-32{ }^{\circ} \mathrm{C}$ [4]. 


\section{Fuzzy Logic}

Fuzzy logic atau logika samar pertama kali dicetuskan oleh Profesor Lotfi A. Zadeh, seorang guru besar University of California. Dalam penyajiannya, variabel-variabel yang akan digunakan harus cukup menggambarkan ke-Fuzzy-annya. Namun disisi lain, persamaan yang dihasilkan dari variabel tersebut haruslah sederhana sehingga komputasinya cukup mudah. Oleh karena itu, Profesor Lotfi A. Zadeh kemudian menyajikannya dengan menentukan fungsi keanggotaan (membership function) dari masing-masing variabelnya [7].

Fungsi keanggotaan (membership function) merupakan suatu kurva yang memiliki rentang antara nilai 0 sampai 1. Misalnya seorang pria yang sedang meminum kopi tidak mutlak menyukai kopi ada tingkatannya, mulai dari sangat suka, suka, agak suka, kurang suka, tidak suka dan sangat tidak suka.

\section{Data Logger}

Data logging merupakan proses pengumpulan dan perekaman data secara otomatis untuk tujuan penyimpanan dan analisis data. Data yang dikumpulkan dapat berasal dari sensor, seperti sensor suhu dan kelembapan. Komponen data logger biasanya berukuran kecil, bertenaga baterai, bersifat portabel dan dilengkapi dengan mikroprosesor dan memori internal untuk menyimpan data dari sensor. Salah satu keuntungan menggunakan data logger adalah kemampuannya menyimpan data secara otomatis setiap 24 jam. Setelah diaktifkan, data logger dapat digunakan dan ditinggalkan untuk merekam informasi dari sensor. Hal ini memungkinkan untuk mendapatkan informasi yang tepat terkait kondisi parameter yang dipantau, seperti suhu dan kelembapan [8].

\section{E. Arduino Uno}

Arduino Uno merupakan board mikrokontroler buatan Italia yang berbasis ATmega328. Mikrokontroler jenis ini bekerja dengan tegangan $5 \mathrm{~V}$ dan memiliki 14 pin digital (input dan output) di mana 6 di antaranya dapat digunakan sebagai output Pulse Width Modulation (PWM). Arduino Uno juga memiliki 6 pin input analog, kristal osilator $16 \mathrm{MHz}$, USB konektor, power jack konektor, header ICSP, dan tombol reset.

\section{F. Sensor DHT22}

DHT22 atau dikenal juga dengan AM2302 merupakan salah satu sensor yang dapat mengukur suhu dan kelembapan relatif udara. Sensor ini memiliki beberapa keunggulan yakni, memiliki tingkat presisi yang tinggi, dapat melakukan pengukuran suhu dan kelembapan relatif dengan rentang yang cukup tinggi dan memiliki konsumsi daya yang rendah. DHT22 bekerja dengan tegangan input 3.3-6VDC. Sensor ini memiliki rentang pembacaan kelembapan antara $0-100 \%$ dengan tingkat akurasi $\pm 2 \% \mathrm{RH}$ serta tingkat sensitivitas pembacaan kelembapan dan suhu yaitu $0,1 \%$ dan $0,1^{\circ} \mathrm{C}$.

\section{PERANCANGAN SISTEM}

\section{A. Perancangan Hardware}

\section{1) Diagram Blok}

Sistem ini dirancang untuk mengontrol pemberian nutrisi pada tanaman yang dibudidayakan dengan metode aeroponik. Parameter yang menjadi acuan dalam pemberian nutrisinya adalah kelembapan dan suhu. Sensor yang digunakan untuk mengukur kelembapan adalah DHT22.

Data yang didapat dari kedua sensor kemudian akan dikirimkan ke Arduino Uno. Pada Arduino, data akan diproses sebagai input Fuzzy logic yang sudah ditentukan membership function-nya. Hasil keluaran Fuzzy logic akan menjadi sinyal bagi aktuator yang dalam hal ini merupakan pompa air untuk melakukan proses pemberian nutrisi ke akar tanaman. Data dari arduino juga akan ditampilkan oleh LCD dan disimpan oleh SD card yang terpasang pada Data Logger Shield.

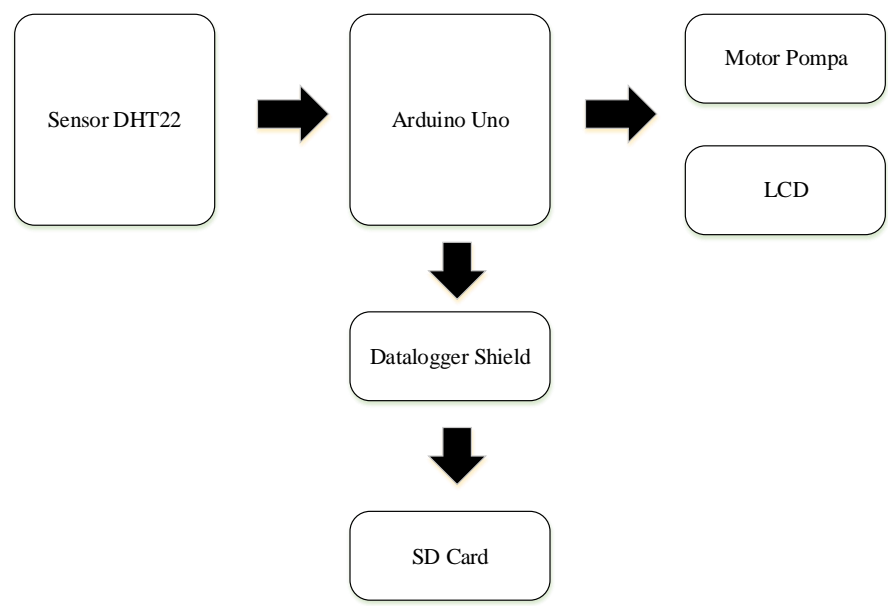

Gambar 1. Diagram blok sistem

\section{2) Desain Media Tanam}

Alat yang dibuat terdiri atas media tanam berupa box plastik. Gambar 2 menunjukkan bagian atas media tanam, di mana terdapat lima lubang yang berfungsi sebagai tempat peletakan tanaman. Sistem mekanik alat terdiri atas sebuah motor pompa. Motor pompa akan mengalirkan nutrisi ke bagian akar melalui pipa yang sudah dipasangi sprayer seperti pada Gambar 3.

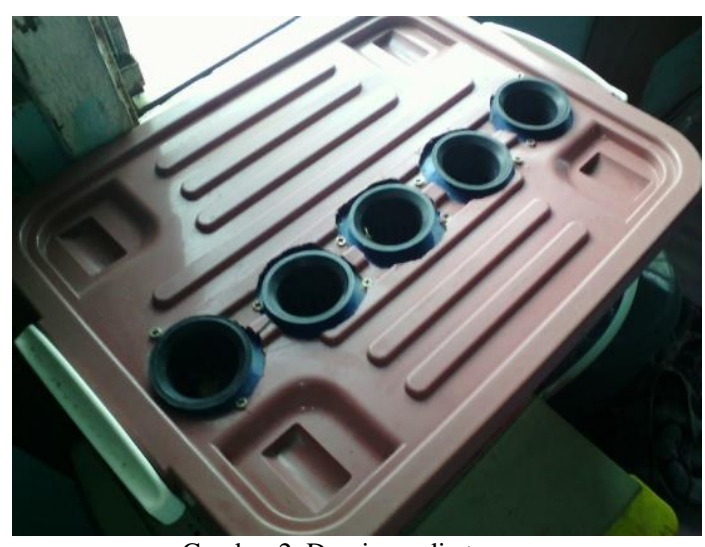

Gambar 2. Desain media tanam 


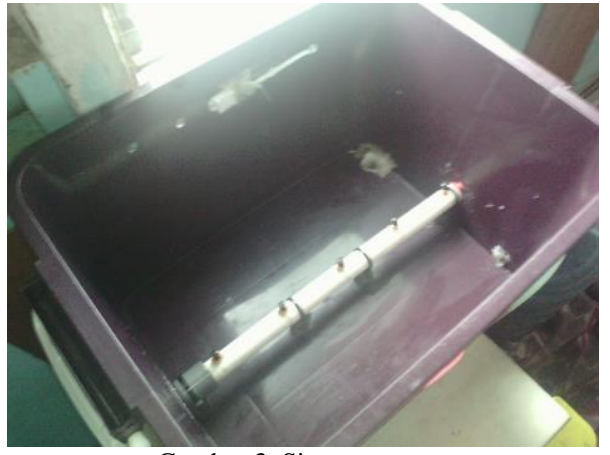

Gambar 3. Sistem sprayer

3) Desain Rangkaian Elektrik

Rangkaian elektrik terdiri atas power supply yang berfungsi sebagai penyuplai daya listrik untuk Arduino dan aktuator. Selain itu terdapat rangkaian transistor TIP122 yang berfungsi sebagai driver motor pompa. Terdapat juga Arduino dan data logger shield yang berfungsi sebagai kontroler.

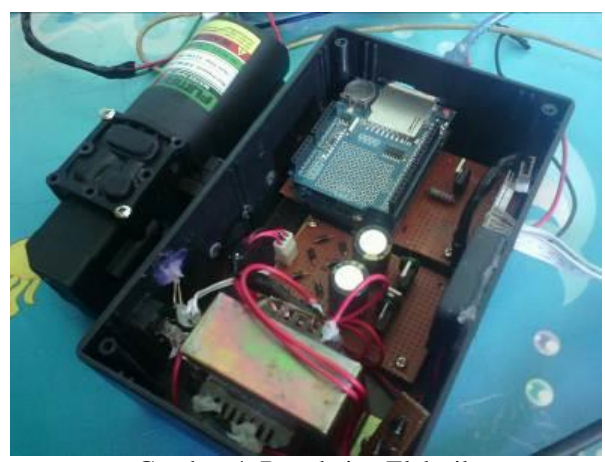

Gambar 4. Rangkaian Elektrik

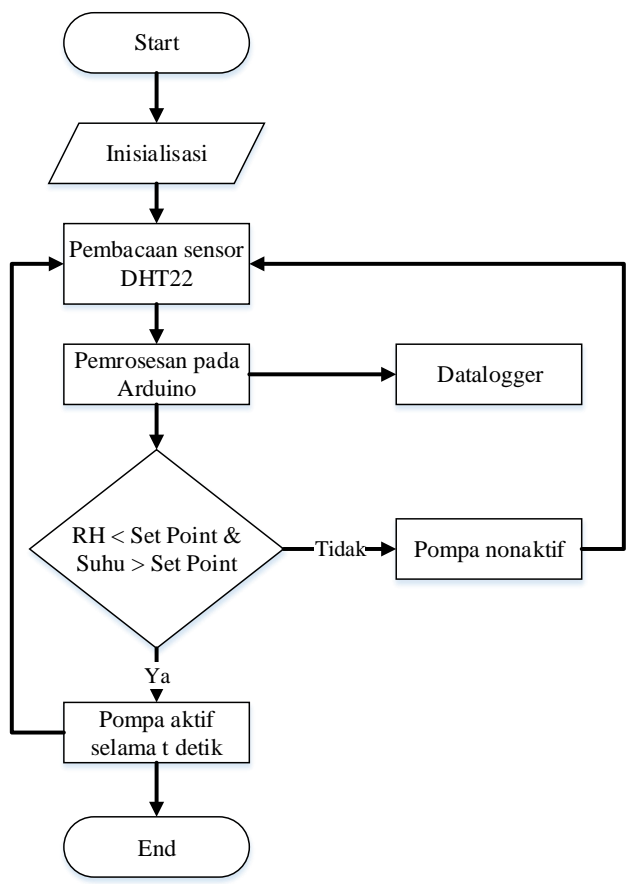

Gambar 5. Flowchart software

\section{B. Perancangan Software}

Ketika sistem telah berjalan, sensor akan memulai pembacaan nilai. Sensor DHT22 akan membaca nilai kelembapan dan suhu di sekitar area perakaran. Data pada sensor akan dikirim ke Arduino untuk diproses sebagai input Fuzzy logic. Selanjutnya, jika nilai kelembapan kurang dari set point $(95 \%)$ serta suhu lebih dari set point $\left(33^{\circ} \mathrm{C}\right)$, maka pompa akan aktif selama $t$ detik. Nilai t detik bergantung pada kelembapan dan suhu. Semakin kecil nilai kelembapan dan semakin besar nilai suhu, maka waktu aktif pompa akan lebih lama, begitu juga sebaliknya. Kemudian, jika tidak memenuhi kondisi maka pompa akan nonaktif. Selain itu, sistem juga memiliki data logger yang dapat menyimpan data dari kontroler ke SD card.

1) Perancangan Fuzzy Logic

a) Membership Function Kelembapan

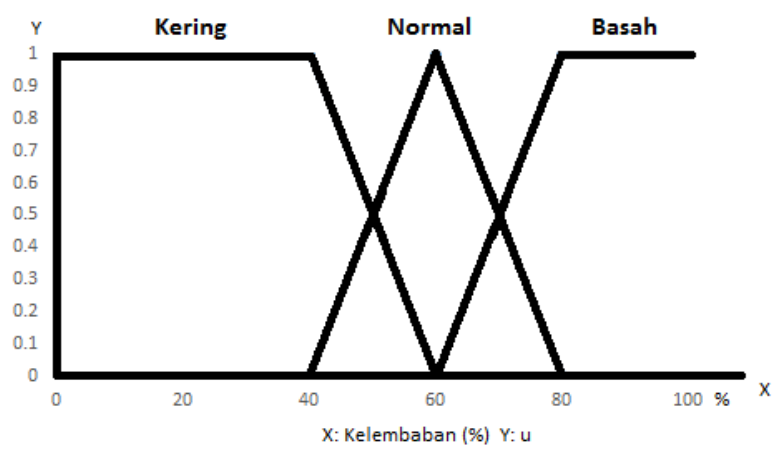

Gambar 6. Membership function kelembapan

b) Membership Function Suhu

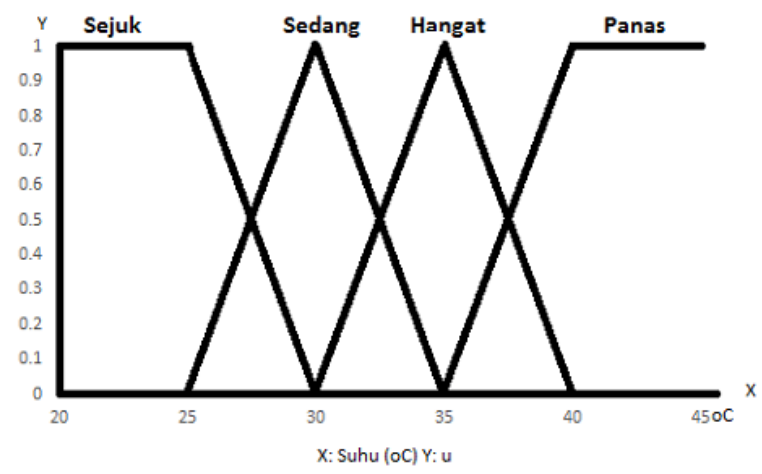

Gambar 7 Membership function suhu 
c)

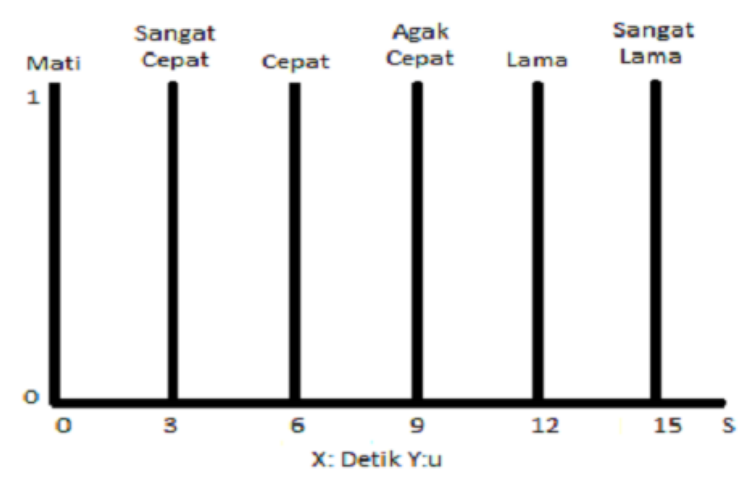

Gambar 8. Membership function output

d)

Rule Evaluation

TABEL I

RULE EVALUATION

\begin{tabular}{|c|c|c|c|}
\hline Suhu/Kelembapan & Kering & Normal & Basah \\
\hline Sejuk & C & SC & MT \\
\hline Sedang & AC & C & SC \\
\hline Hangat & L & AC & C \\
\hline Panas & SL & L & AC \\
\hline
\end{tabular}

Keterangan:

- MT : Mati

- SC : Sangat Cepat

- $\mathrm{C}$ : Cepat

- AC : Agak Cepat

- L : Lama

- SL : Sangat Lama

\section{PEngujian Dan ANALISA}

Dalam prosesnya, ada dua kali pengujian yang dilakukan. Pertama, pengujian dengan sistem timer pada tanggal 14-21 April. Pada pengujian dengan metode timer, sistem akan bekerja dengan sistem ON-OFF, dimana pompa akan menyala selama 5 detik dan mati selama 15 menit. Sedangkan pengujian kedua dilakukan dengan menggunakan Fuzzy logic pada tanggal 28 April - 5 Mei. Pengujian dengan metode Fuzzy, sistem akan bekerja berdasarkan suhu dan kelembapan di mana set point suhu yaitu $33^{\circ} \mathrm{C}$ dan kelembapan $95 \%$. Ketika suhu dan kelembapan terukur melewati set point tersebut, maka pompa akan menyala. Kedua pengujian tersebut dilakukan untuk mengetahui pola data yang didapat dari kedua metode tersebut. Berikut analisa pengujian hari ke2 baik menggunakan sistem timer maupun Fuzzy.

\section{A. Grafik Pengujian Hari Ke-2}

Pengujian hari ke-2 pada sistem timer berlangsung pada tanggal 16 April. Sedangkan pengujian dengan sistem Fuzzy hari ke-2 berlangsung pada tanggal 30 April. Gambar 9 dan 10 menjelaskan data pengujian hari ke-2 sistem timer dan Fuzzy. Terlihat pada Gambar 9 bahwa suhu mengalami kenaikan pada siang hingga sore hari dan cenderung menurun pada saat malam hari. Sedangkan nilai RH hanya mengalami penurunan pada sore hari dari pukul 16:19:08-17:04:29. Sedangkan pada Gambar 10, yaitu grafik yang menunjukkan pengujian hari ke-
2 dengan sistem Fuzzy, menunjukkan terjadinya kenaikan suhu melewati batas maksimalnya yakni $33^{\circ} \mathrm{C}$. Namun pola data pada grafik tersebut lebih terkontrol dibandingkan pola data pada Gambar 9 yang cenderung mengalami perubahan drastis terutama siang hingga sore hari. Nilai RH pada gambar 48 relatif stabil.

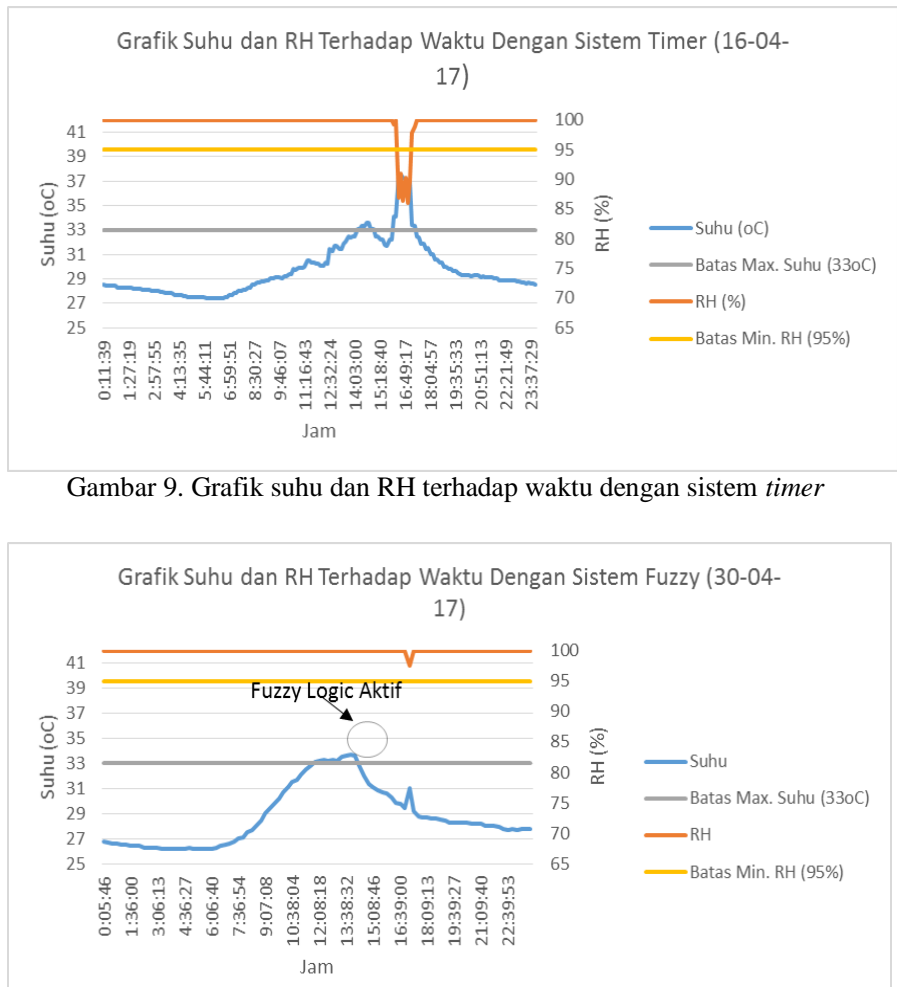

Gambar 10. Grafik suhu dan RH terhadap waktu dengan sistem Fuzzy

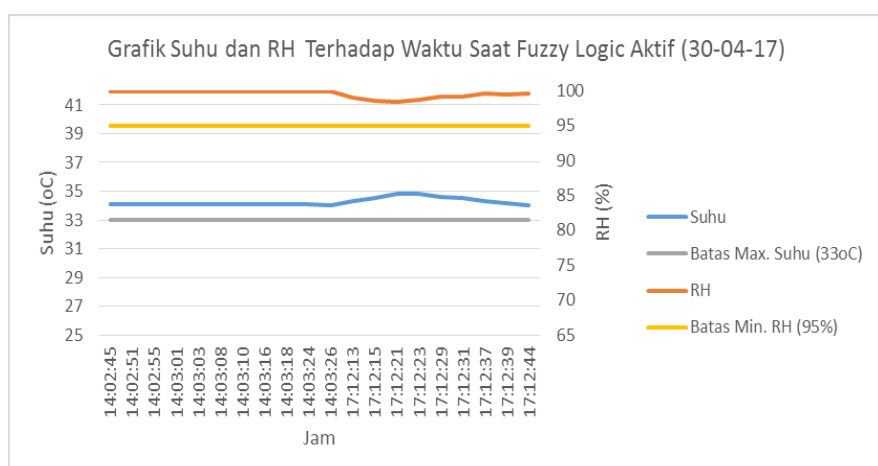

Gambar 11. Grafik suhu dan RH terhadap waktu saat Fuzzy logic aktif

Grafik pada Gambar 11 menunjukkan nilai suhu dan $\mathrm{RH}$ saat Fuzzy logic aktif di hari ke-2 pengujian. Aktifnya Fuzzy logic menandakan pompa yang juga aktif untuk melakukan penyiraman ke bagian akar tanaman pada pukul pukul 14:02:45-14:03:26 dan 17:12:14-17:12:44 dengan jeda 2 detik setiap penyiramannya. Nilai error suhu yang ingin dicapai yaitu $1^{\circ} \mathrm{C}$ ( set point $33^{\circ} \mathrm{C}$ ) sehingga dibutuhkan beberapa kali penyiraman untuk mencapai nilai suhu $34^{\circ} \mathrm{C}$. Sedangkan untuk nilai $\mathrm{RH}$ cenderung stabil namun tetap berada diatas batas minimal RH yang diinginkan yaitu $95 \%$. 


\section{B. Hasil Pengukuran Panjang Tanaman}

Selama pengujian dengan sistem timer maupun Fuzzy, dilakukan pengukuran panjang batang tanaman kangkung menggunakan mistar. Gambar 12 ini merupakan hasil pengukurannya.

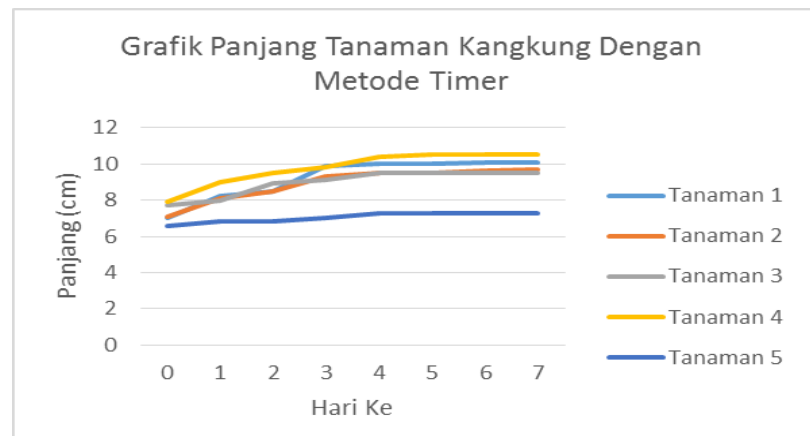

Gambar 12. Grafik panjang kangkung berdasarkan pengujian metode timer

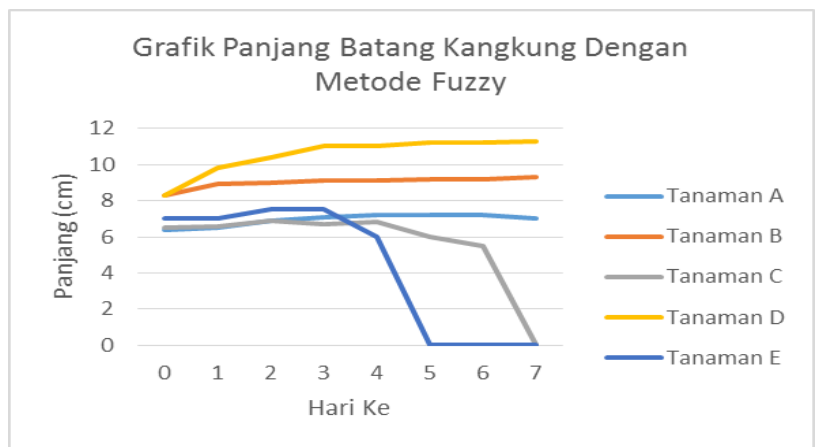

Gambar 13. Grafik panjang kangkung berdasarkan pengujian metode Fuzzy

Gambar 12 menunjukkan panjang tanaman kangkung selama 7 hari pengujian dengan metode timer (14-21 April). Panjang tanaman kangkung awal pengujian (hari ke-0) berkisar antara 6.6-7.9 $\mathrm{cm}$. Sebagaimana ditampilkan pada grafik, tanaman kangkung yang digunakan sebagai objek pada pengujian dengan metode timer ini mengalami pertumbuhan yang cukup baik di 4 hari pertama. Namun memasuki hari ke 5-7 panjang tanaman tidak lagi mengalami kenaikan yang signifikan.

Sedangkan Gambar 13 menunjukkan panjang tanaman kangkung selama 7 hari pengujian dengan metode Fuzzy. Pengujian dilakukan pada tanggal 28 April - 5 Mei. Panjang tanaman kangkung awal pengujian (hari ke-0) berkisar antara $6.4-8.3 \mathrm{~cm}$. Pertumbuhan tanaman kangkung cukup signifikan terutama tanaman B dan tanaman D. Sedangkan tanaman A pertumbuhannya relatif konstan. Lain halnya dengan tanaman $\mathrm{C}$ dan E. Kedua tanaman mengalami kenaikan tinggi yang cukup baik di 3 hari pertama namun pada hari ke 4-7 tanaman $\mathrm{C}$ mengalami penurunan tinggi tanaman akibat adanya daun yang layu. Penurunan tinggi ini terjadi hingga hari ke-7 dimana tanaman $\mathrm{C}$ mati. Sedangkan tanaman $\mathrm{E}$ telah mengalami kelayuan pada hari ke-5 sehingga menyebabkan tanaman mati. Adanya tanaman yang mati dipengaruhi banyak faktor. Mulai dari penyiraman, komposisi nutrisi dan penyinaran matahari. Ada juga yang disebabkan oleh faktor internal tanaman itu sendiri seperti kualitas dan usia biji, sehingga sistem ini tidak mempengaruhi pertumbuhan tanaman secara mutlak.

\section{KeSIMPULAN}

Berdasarkan penelitian yang telah dilakukan, disimpulkan bahwa penerapan sistem otomatisasi dalam budi daya tanaman aeroponik dapat terlaksana dengan baik. Alat mampu bekerja menyuplai larutan nutrisi berdasarkan suhu dan $\mathrm{RH}$, namun dalam prosesnya terdapat error suhu sebesar 3.32\%-5.28\%. Penyebab terjadinya hal tersebut yaitu:

a) Suhu udara kota Batam yang cenderung panas di siang hingga sore hari, sehingga mempengaruhi suhu di dalam ruang media tanam.

b) Suhu larutan nutrisi yang juga terpengaruh suhu luar sehingga membutuhkan waktu yang relatif lama untuk menurunkan suhu di dalam ruang media tanam.

c) Posisi media tanam yang berada dalam paparan tidak langsung matahari pada siang hingga sore hari.

Pola data pengujian dengan sistem timer cenderung mengalami perubahan drastis saat keadaan lingkungan panas terutama siang hingga sore hari. Hal ini terjadi karena sistem bekerja hanya berdasarkan timer tanpa memperhatikan suhu dan RH pada ruang media tanam. Berbeda halnya dengan pengujian sistem Fuzzy dimana perubahan yang terjadi tidak terlalu drastis karena pada saat melewati batas suhu dan $\mathrm{RH}$ yang ditetapkan, maka pompa akan aktif sehingga mencegah perubahan ekstrim suhu dan RH pada ruang media tanam.

\section{REFERENSI}

[1] Lakkireddy K. K. R., Kasturi K., Sambasiva Rao K.R.S., "Role of Hydroponics and Aeroponics in Soilless Culture in Commercial Food Production", Journal of Agricultural Science \& Technology, Vol. 1, Issue. 1, pp. 26-35, April 2012.

[2] Nugaliyadde MM, De Silva HDM, Perera, R, Ariyaratna D, Sangakkara UR, "An aeroponic system for the production of pre-basic seed potato", Ann. Sri Lanka Department Agric. Vol. 7, pp. 199-288, 2005.

[3] Imma Farran, Angel M. Mingo-Castel, "Potato Minituber Production Using Aeroponics: Effect of Plant Density and Harvesting Intervals", American Journal of Potato Research, Vol. 83 No.1, pp. 47-53, Januari 2006.

[4] Liferdi L, Cahyo Saparinto. "Vertikultur Tanaman Sayur", Jakarta, Penebar Swadaya, 2016

[5] Wijayani A., D. Muljanto, Soenoeadji, "Pemberian nitrogen pada berbagai macam media tumbuh hidroponik: pengaruhnya terhadap kuantitas dan kualitas buah paprika (Capsicum annuum var. Grossum)". Jurnal Ilmu Pertanian, Vol. 6 No. 2, pp. 8-13, 1998.

[6] Fadhil, Muhammad., Bambang Dwi Argo, Yusuf Hendrawan, "Rancang Bangun Prototype sistem timer RTC DS1307 Berbasis Mikrokontroler Atmega16 pada Tanaman Aeroponik", Jurnal Keteknikan Pertanian Tropis dan Biosistem, Vol. 3 No. 1, pp. 37-43, Februari 2015.

[7] Sudrajat, "Dasar-dasar Fuzzy Logic", Jurusan Matematika, Fakultas Matematika dan Ilmu Pengetahuan Alam, Universitas Padjadjaran, Bandung, 2008.

[8] Fachri, Muhammad Rizal., "Rancangan dan Analisis Data Logger Multichannel Untuk Menentukan Performansi Panel Surya", Tesis, Program Studi Magister Teknik Elektro, Program Pascasarjana, Universitas Syiah Kuala Darussalam, Banda Aceh, 2015. 